\title{
Impact of Micro Credit on Poverty Reduction in Dega Damot Woreda, Amhara, Ethiopia
}

\author{
Abiot Animaw Semegn ${ }^{1} \quad$ Narendra K Bishnoi ${ }^{2}$ \\ 1.Research Scholar, Department of Economics, Guru Jambheshwar University of Science \& Technology, Hisar \\ 2.Professor, Department of Economics, Guru Jambheshwar University of Science \& Technology, Hisar
}

\begin{abstract}
The challenge Ethiopia is facing today is to reduce poverty and gear up the living standard of its people. One of the poverty reduction policies of the country therefore is the introduction of micro financial institutions to empower the economically marginalized segments of the society. Amhara credit and saving institution (ACSI) is one of the largest micro finance institutions operating in Ethiopia established in accordance with proclamation no. 40/1996 The objective of this study, therefore, is to find out whether Amhara Credit and Saving Institution (ACSI) has made changes on living standard of the clients based on tropical livestock unit and Income change, while the other objective is whether ACSI reduces the income gap between program clients and non-clients. Primary data were collected through structured questionnaire from clients and non-clients using simple random sampling method. Both are quantitative and qualitative in nature.Descriptive analysis and dichotomous binary model were applied in the study. The impact study was analyzed based on socio economic variables. The finding of the study indicated that the ACSI's micro financing program has made positive contribution to its clients in relation with the observed variables in the study area. Therefore, attention should be given in strengthening the prevailing operation of the Amhara Credit and Saving Institution.
\end{abstract}

Keywords: Impact; ACSI; logit regression; Ethiopia; Gini coefficient; Tropical livestock unit.

DOI: $10.7176 /$ RJFA/11-23-05

Publication date: December $31^{\text {st }} 2020$

\section{Introduction}

By any standard, the majority of people in Ethiopia are among the poorest in the world (DERCON and KRISHNAN, 1998; IMF, 1999; RAHMATO and KIDANU, 1999; WORLD BANK, 2001). Poverty seems to persist in large sections of the rural society with little hope for a substantial improvement of the living conditions of the rural poor in the near future. In order to combat such debilitating poverty considering very scarce financial resources available to be allocated for the purpose, we have to understand the determinants of poverty in rural Ethiopia. For this, the poor must be properly identified and an index taking the intensity of poverty suffered by the poor into account needs to be constructed

Over the last ten years, the country has achieved double digit growth in real terms, averaging $10.6 \%$ per year, which is the second fastest in Africa after Angolai and even surpasses that of China (10.2\%)(Deloitte \& Touche, 2014)

The policy makers always support micro finance institutions to reduce poverty. Poverty reduction has been the objective of unprecedented attention at international summits in the 1990s (Jonathan, 2002)

Webster and Fidler (1999), viewed the access to financial service to the poor in terms of its ability to help them to escape from poverty. However, the prevailing operation of the formal financial institutions is inefficient to provide sustainable credit facilities to the poor in countries like Ethiopia.

The assumption according to Aguilar (1999), is that by integrating the poor into productive economic activities, development would be promoted automatically through micro finance.

However, (Aguilar 1999; Hulme 2000; and Wright 1999) noted that recently policy makers, donors and practitioners have been in increasing distrust whether the expected results have been achieved. Thus, a number of impact assessment studies have been conducted in Asia, Latin America and Africa where the majority of the society are poor and micro finance programmes are being carried out.

The objectives of most of these studies were to assess the impacts of having access to microfinance services on incomes and their sources, standards of living, better health, empowerment, children's education as well as better self-image and decision-making power as a direct result of the loans. These studies, however, reported mixed results like little positive change in alleviating poverty (Dunn and Arubuckle,2001); accumulation of increased working capital by the poor, increased investment in fixed assets, self-employment, and more incomes (Wright,1999); and increased debt liability (Rahman,1999 and Hulme ,2000). According to Hulme, 1997, microfinance impact assessment studies have been undertaken at different levels such as individual, household, institutional and community levels. For instance, the conventional performance evaluation of microfinance institutions (MFIs) with emphasis on financial sustainability and outreach give overriding emphasis to financial criteria.

Thus, it is critical for microfinance impact assessment practitioners to be sensitive to the impact of the 
programmes on the clients rather than financial sustainability of the providing institution. Hence, the starting point of this study is about whether the programmes of Amahara credit and saving institution Feresbet sub-branch (ACSI) are making positive changes on living standard of its clients.

\section{Review of Literature Impacts of Microfinance}

The impact of micro finance is not a simplistic debate on whether it is trans formative or devastating; it is much more complex. Thus, literature reviews of empirical research on the impact of micro finance on the poor found controversial (and inconclusive) findings (Makina and Malobola (2004) classify such findings into a three-fold typology:

1. findings related to beneficial socioeconomic impacts, such as income stability and growth, reduced income inequality, reduced vulnerability, employment, nutrition and health improvements, school attendance, strengthened social networks, and women empowerment

2. Those findings which are related to the negative effects, such as unaffected poverty levels, the exploitation of women, increased income inequality, increased workloads, creating dependencies, high interest rates and loan repayment, and creating barriers to sustainable local economic and social development

3. Those studies that show mixed impacts. For example, benefits for the poor but not for the poorest.

\section{The impact of microfinance on the poor}

The question of outcome arises once poor people do access financial services. One of the vital debates in micro finance is expressed by Brau and Woller (2004) as the trade-off between sustainability, and financial selfsufficiency, the depth of outreach, and the social welfare of service recipients. Roodman, (2010) refers to the latter as judging micro finance by whether it increases freedom, reduces poverty, and builds industries.

With the one goal of micro finance seen as reducing poverty, changes in income levels of individuals and households are many times used as a measure of the impact of micro finance (Makina and Malobola, 2004). But Wright (1999) highlights why income levels cannot be the only measure: increasing income does not mean that poverty is reduced, as it depends on what the income is used for.

Studies of the impact of micro finance on the poor will have different outcome variables such as increased consumption, income stability and income growth, reduced inequalities, nutrition improvements, health and education outcomes, employment levels, empowerment indicators, reduced vulnerability to shocks, strengthened social networks, and strengthened local economic and social development, and can vary according to who has been reached by these micro finance services (e.g. women, the poorest). Kabeer (2003:110) refers to such dimensions of impact as cognitive, behavioral, material, relational and institutional changes. Brau and Woller (2004) and Kabeer (2003) further highlight that impact studies should not only look at individual and/or household-level impacts, but also look at impacts on community, economy and national levels.

\section{Assessing the Impact of MFI's Micro Financing Scheme on Poverty Reduction}

Khandker (1999) argued that the immediate impact of having access to credit from a micro credit program is on employment and income in which these may have impact on other outcomes such as consumption, nutrition, contraceptive use, fertility and education.

According to Meehan (2000), there are many supporters of micro credit provision who would agree that well designed lending programs could improve the income of the poor people. However, there is the existence of methodological difficulties associated with the measurement of the impact of the program towards poverty reduction (Fidler and Webster (1996). They proposed the descriptive approach in assessing the impact of microfinance on poverty reduction by comparing the beneficiaries' outcomes before and after loan or outcomes of clients and non-clients.

Joanna Legerwood (1999) stated the three broad categories of impacts of microfinance activities.

- Economic impacts (business expansion, income, accumulation of wealth and consumption).

- Socio-political or cultural impacts (changes in favor, changes from barter to monetized economy, hope for changes in power, redistribution of assets, nutrition and education).

- Personal or psychological impacts.

According to Joanna legerwood an impact from one of these categories can in itself cause an impact on one or more of the others. The poor participate in micro-credit programs in the expectation that borrowing will increase their income and sustain self-employment.

Khandker (1999) argued whether participation in micro-credit programs does in fact reduce poverty in terms of consumption and help increase income and employment on a sustained basis could be measured directly. The benefits of program participation can also be measured indirectly, by measuring changes in socio-economic outcomes. This implies that the effects of micro-credit programs on participants can be measured in terms of consumption, nutrition, employment, net worth, schooling, contraceptive use and fertility. The study argued that 
changes in income and employment among program participants might affect the living standard of the poor. There are two important factors that determine the overall impact of the program. These are the growth potential of activities financed by the micro credit programs and the extent of credit market imperfections that are resolved with enhanced availability of credit.

According to AIMS (2000), the purpose of an impact assessment is to answer the question of whether a project leads to change that is different from what would have happened without the intervention, or whether the program increases the probability of that change. In the context of the rapid growth and evolution of microfinance industry, impact assessment is a critical to classify whether or not the changes occur on the livelihood of the clients. Establishing impact is making a credible case that the program led to the observed or stated changes, meaning that the changes are more likely to occur with program participation than without program participation. It does not imply that the changes always occur from program participation. Rather, it increases the probability that the changes will occur.

The type of change we are looking for can occur for multiple reasons, many of which are not related to program interventions (AIMS, 2000). There are factors that enhance or constrain opportunities for change but are not directly linked to the program intervention such as gender of client, number of household members, price of business inputs and external factors.

According to AIMS, searching for impacts requires lens on the full range of family/household economic activities because the micro enterprise is firmly embodied in the family/household especially among poorer families. How the micro enterprises fit into overall economic strategies depends on the following factors.

- The composition of the family, which will vary in different locations and cultures.

- Decision-making within the family about investments and the selection of productive activities.

- How the family is linked extremely to larger social networks through which it gives and receives resources.

Ledgerwood (1999) argued that most microfinance institutions see microfinance as a cost effective means of poverty reduction, but the detailed intentions and expectations of microfinance programs can differ considerably. Impact of microfinance activities may fall at the level of the economy itself. According to Hulme (2000) there are three elements of the framework for the study of impacts. The first is the specification of levels at which impacts are assessed. The second is the specification of the types of impact that are to be assessed. The third is models to be used for the study i.e. a model of the impact chain that the study is to examine.

\section{Impact Assessment Levels of}

Khandker and Ledgerwood (1999) stated that impact can be assessed at household, enterprise, individual and community levels.

There are two major schools of thought that are prominent in impact assessment of microfinance programs according to the view of Yaron(1997). The first one purely focuses on the organization or company and its operation. This approach focuses on institutional outreach and its sustainability. The assumption is that if both outreach and sustainability have been enhanced, then the intervention is judged to have a beneficial impact as it has widened the financial market, which in turn extends the choice of people looking for credit and saving services. The second approach is the one, which focuses on the intended target groups or clients.

According to AIMS (2000), the framework suggests that impact occurs at the levels of household, enterprise, individual and community. At the household level, microfinance contributes to net increase in household income, asset accumulation and labor productivity.Income invested in assets such as saving and education increases household economic security by making it possible to meet basic needs. This relationship clarifies paths of impact by which microfinance interventions can contribute to the goals of poverty alleviation and economic growth, and thus, households improve their economic security. To assess change within this relationship, impact can be assessed in the movement of household's livelihood toward or away from greater economic security.

\section{Impact of microfinance at Household level}

According to Yaron (1997), the impact of program placement on village level average income, employment and poverty is estimated by fitting a village level regression that measures the differential impacts of program placement at the village level while controlling for observable characteristics of the village. Group-based credit program may be efficient for joint production and consumption behavior of households. It may also be beneficial for such households to borrow from group-based credit program, which charges less than informal lenders, in order to make more efficient use of available resources, mainly family labor. In this case, the evaluation of the effects of program participation on households' resource allocation is based on this efficiency argument (Khandker, 1999).

Assessing the impact of credit involves one basic problem: unless households are shown to be credit constrained (meaning that households are constrained by a lack of liquidity and do not have access to credit to solve their credit problems), it may be difficult to show the impact of credit on behavioral outcomes such as income and employment. 
Khandker (1999) recommended that rather than formally test whether borrowers of group base programs are credit constrained, he assumed that program participants were credit constrained by program design. This assumption seems valid for several reasons. First, in the case of group-based lending to the landless, the time path of credit allocated to members is part of the dynamic optimization problem of a group, and the level of credit provided to each individual in the group is tailored to fund a new self-employment project of certain size. Second, the cost of credit includes not only the interest rates but also the timing of repayment and the penalties associated with defaults. Third, group-based credit is packaged with both responsibilities (meeting attendance, forced saving, shared default risk) and benefits (training, insurance, and consciousness-raising), which are likely to make the cost of credit endogenously determined by household characteristics. Finally, the close monitoring aspects of groupbased lending make group credit no fungible.

If there were no monitoring of the use of borrowed funds and no group responsibility and decision-making in the lending program, individuals would likely want to borrow much more than they actually do in order to capture the premiums associated with the soft terms of the loans. The most important effect of borrowing from a micro credit program is its impact on capital expenditure. Because borrowers are poor, increase in consumption as a result of borrowing from a micro credit program constitute an immediate welfare gain. Micro credit programs facilitate self -employment, mostly in rural non-farm activities that can be undertaken at home without high transactions costs.

\section{Impact Indicators of Poverty}

The framework developed by Ledgerwood (1999) defines domains of impact indicators to measure impact at the household, enterprise, individual and community levels. At the household level, income, assets, consumption expenditure and basic services are indicators of impact assessment. At the enterprise level, five domains of development include the resource base, production process, management, markets and financial performance. At the individual level, three domains of well-being include independent control of resources, leverage in households' decision-making units and community participation.

At the community level, four domains of development include net changes in employment and income, forward and backward linkages, social networks and civil participation. The changes of these indicators imply that the movements at different levels toward or away from greater economic security are believed to suggest the role of microfinance interventions in expanding options for poor women and men in relation to the broader development goals of poverty alleviation and economic growth (Chekol kidane (2002). In addition, domains of household security include income, assets and expenditures according to AIMS (2000).

\section{Models of Impact Assessment}

In the case of microfinance impact assessment, one needs to conceptualize how microfinance leads to changes and what changes are reasonable to expect given the services provided and loan conditions. The assumption is that interventions will change human behaviors and practices in ways that lead to the achievement or raise the probability of achievement of desired outcomes. Therefore, models have to be identified to capture the explanatory variables.

A variety of multivariate statistical techniques can be used to predict a binary dependent variable from a set of independent variables. When one or more of the explanatory variables in regression model are binary, it can be represented as dummy variable and appropriate models are expected to be applied. However, the application of the linear regression model when the dependent variable is binary is more complex and /or even not efficient (Pindyck and Rubinfed, 1981). The dependent variable, which is dichotomous taking on two values, zero and one, requires the use of qualitative response models. In this regard, the ordinary least squares (OLS), descriptive analysis, multiple regression models, linear probability models, Logit, Probit and Tobit models are the possible alternatives.

However, several estimation problems can be raised from some of these alternatives. According to Gujarati (1992), OLS estimation methods have been used to see the effects of independent variables when the dependent variable is continuous.

The author noted that using the linear probability models where the dependent variable takes either 0 or 1 is found to have several problems such as non-normality, heteroscedasticity of disturbance term, non-fulfillment of the criteria that the probability of the occurrence within the range $0-1$ and lower value of coefficient of multiple determinants (R2) as a measure of goodness of fit. Using linear probability model may generate predicted values outside the 0-1 intervals, which violates the basic principles of probability. To alleviate these problems Gujurati (1992) argued that the most widely used qualitative response models are the Logit and Probit models. Comparing with descriptive analysis model Feder (1985) noted that the Probit and Logit models appear to be preferable to discriminate function in analyzing studies involving qualitative choices. An extension of the Probit model is the Tobit model. The Probit model is associated with the cumulative normal probability function, the Logit model assumes cumulative logistic probability distribution whereas the Tobit model assumes censored regression model. 
Such models including the Logit model are usually estimated by the maximum Likelihood methods (MLM). Since the logistic regression model is non-linear, an iterative logarithm is necessary for parameter estimation (Gujarati 1992). More important, the advantages of Probit, Logit and Tobit models over the linear probability model are that the probabilities are bound between 0 and 1. Moreover, they best fit to the non-linear relationship between the probabilities and the explanatory variables.

Gujarati (1992), Maddala (1988) and Feder (1985) have recommended Tobit model for function forms with limited dependent variables that are continuous between 0 and 1, Logit and Probit models for discrete dependent variables. For this study, therefore, Logit model was used in addition to the descriptive statistics.

\section{Empirical Evidence}

Different studies in different disciplines used different approaches to assess impact. Khandker (1999) studied the impact of three micro credit institutions in Bangladesh on selected household levels. The study found that the most important effect of borrowing from a micro-credit program is its impact on per capita expenditure. The study also pointed out that the participation in group-based microfinance shows positive and significant impacts for school enrollment, asset holdings, consumption, nutritional status and household net worth of borrowers in all three programs.

Joanna Ledgerwood (1999) pointed that successful microfinance institutions contributing to poverty reduction are particularly effective in improving the status of the middle and upper segments of the poor. However, clients below the poverty line were worse-off after borrowing. Berahnu (1999), Meehan and Teferi (2000) concluded that microfinance scheme in Ethiopia has a positive impact on household nutrition, asset accumulation and net welfare of the program participants despite the fact that operations of MFIs are a recent phenomenon in the country.

An impact assessment study was conducted by Meehan on the performances of DECSI in 2000. The study was based on both primary and secondary data to analyze the impacts of the services of the institution. Sample Respondents were asked to assess the impact of DECSI financial services on their household income. According to him majority of respondents reported a considerable, a few reported relatively modest increases in their household income, few said there had been no change in their economic status and very few reported they were worse off. The result of the study stated that women were more likely to have taken on new activities and more likely to complain that the loan size was insufficient.

Berhanu (1999), from his study of micro-credit and poverty alleviation in Ethiopia, identified that more than $70 \%$ of the respondents under his study reported the positive contribution towards employment creation, income generation, improved access to health and educational facilities as well as household nutrition. Teferi (2000) also argued the positive contribution on the average monthly total income of the program participants from his study of microfinance and the poor in Tigray.

Berhanu (1999) and Teferi (2000) found that the performance of saving mobilization from the clients was not satisfactory since the majority of the respondents have no saving accounts after the loan scheme even though there seems to raise the number of saving accounts of the clients. From the study of Berhanu (1999) and Teferi (2000), it is possible to estimate the performance of loan repayment rate of ranging between $79 \%$ and $98 \%$. According to the study of Tsehay and Mengistu (2002) microfinance intervention among poor women in Ethiopia has made some positive effects that made a difference on the socio-economic empowerment of the women clients.

\section{Research Design}

The study was conducted in west Gojam Zone of Amhara National Regional State in Degadamot woreda. Both quantitative and qualitative data were used to measure the impact of the program in the survey study. Primary and secondary data were also used.

\section{Sampling Method and Sample Size determination}

Two sample groups from the total population were identified so as to select respondents for the survey. The first group consisted of those who are in the waiting list. While the second group consisted of people who have been in the program for more than two years. The selection was conducted randomly. The list of people from the institution was used as a sampling frame.

Three stages sample design procedure was adopted for the survey.

The first stage was the selection of sample branch of the ACSI.

$\rightarrow$ The second stage was the selection of sample kebeles.

$\rightarrow$ The third was the selection of sample respondents from the selected kebeles.

Participation categories: it is necessary to first determine which observations would be included in the treatment and the control sample in order to analyze the data. The approach is to differentiate between the experiment groups and control groups according to the participation status of the households with the program during the survey period. In addition, each study accorded special attention to the specific subgroups of the clients' sample that is 
defined in terms of settlement area or gender.

The treatment (experiment) sample: included all households who are classified as frequent clients of the program. Specifically, the treatment sample included all households who are clients of the program for more than two years or those who have taken loan twice or more.

Control sample: included all households who are classified as new entrants of the program. Specifically, the control sample included all households who had never received services from the program but who are in the waiting list to take loan for the first time.

\section{Sample Size Determination}

The number of sample households used in this study was determined using the following formula (Cochran, 1977) from the total population 6597 is 276 . In terms of length of program participation, 146 respondents were selected from frequent borrowers while the remaining 130 were from non-clients who make up the control group. More specifically the composition of the sample is shown below in table 1

Table:1. Composition of sample respondents

\begin{tabular}{cccc} 
Type of respondents & $\begin{array}{c}\text { Active clients (Experimental } \\
\text { group) }\end{array}$ & $\begin{array}{l}\text { Non clients } \\
\text { (control group) }\end{array}$ & Total \\
\hline
\end{tabular}

\begin{tabular}{llllll} 
& Male & Female & Male & Female & \\
\cline { 2 - 5 } & & & & & 32 \\
Urban respondents & 11 & 19 & 59 & 121 \\
Rural respondents & 74 & 42 & 73 & 57 & 155 \\
\hline Total & 85 & 61 & & 25 & 276 \\
\hline
\end{tabular}

\section{Method of Data Analysis}

As suggested by USAID's AIMS project the cross-sectional impact analysis method was applied between frequent borrowers who have been in the program for two years or more and non-clients as a control group. After collecting the data, a mix of statistical and econometric tools were employed so as to obtain the best possible measure regarding the impact of credit on improving the life of the clients.

\section{Model Specification}

An appropriate measure of the impact of the microfinance services on economic status of the clientele, which is reflected on income level, is treated as a dichotomous dependent variable (it takes 1 if income is improved and 0 otherwise). The functional relationship between the probability of improvement in income and explanatory variables is specified as:

Where: $Y=$ Average yearly income of respondents

$\mathrm{Xi}=\mathrm{is}$ a vector of explanatory variables that include: type of the respondents, settlement of the respondents, sex of the respondents, age of respondents, educational status of the respondents, , family size, individual voluntary savings, loan size ownership of land in hectare

$\mathrm{U} 1=$ Error term

The explanatory variables that affect the economic status of the respondents were expressed both qualitatively and quantitatively. Where the dependent variable is dichotomous, many studies show that Probit and Logit models are appropriate. Since the Logit model is simpler in estimation than Probit model (Alderic and Nelson, 1984), Logit model is preferred to the Probit, model for this study for the following reasons. First, it is easy to manipulate and simple to comprehend. Second, the data will be dichotomous and therefore, Logit is the best to use. Third, several studies have used this model while dealing with similar topics with this thesis.

Therefore, following Gujarati (1992), the Logit distribution function is specified as:

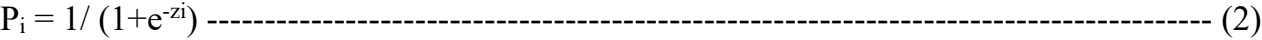

$$
\begin{aligned}
& Z_{i}=\beta o+\beta_{1} X_{1 i}+\beta_{2} X_{2 i}+---+\beta_{n} X_{n i}-- \\
& \mathrm{P}_{\mathrm{i}}=1 /\left[1+\mathrm{e}^{-(\beta \mathrm{o}+\beta 1 \mathrm{X} 1 \mathrm{i}+\beta 2 \mathrm{X} 2 \mathrm{i}+---+\beta \mathrm{nXni})}\right]
\end{aligned}
$$

Where, $\mathrm{Pi}=$ Probability of improvement in income in relation with the explanatory variables

$\mathrm{e}^{\mathrm{zi}}=$ Irrational number to the power of $\mathrm{zi}, \mathrm{z}^{\mathrm{i}}=\mathrm{A}$ function of $\mathrm{n}$ explanatory variables

$\beta \mathrm{s}=$ parameters

Thus, the probability of improvement in income in relation with the explanatory variables is explained based on the sign of the coefficients. The parameters tell how the economic status of the clients and non-clients changes as explanatory variables change. The positive sign of the parameters shows the trend that the changes of the variable are greater in clients than non-clients 
Table 2: List and Description of Variables of Impact at Household Level

\begin{tabular}{|l|l|}
\hline Variables & Description of \\
\hline Y & $\begin{array}{l}\text { Average annual income } \\
1=\text { improved } 0=\text { not improved }\end{array}$ \\
\hline RESPO & $\begin{array}{l}\text { Types of respondents } \\
1=\text { clients } 0=\text { non clients }\end{array}$ \\
\hline LS & Loan size \\
\hline SEX & $\begin{array}{l}\text { Sex of respondents } \\
1=\text { male } 0=\text { female }\end{array}$ \\
\hline AGE & Age of respondents \\
\hline SETR & Settlement of respondents \\
\hline HHEDU & Household educational level \\
\hline HHSIZ & Household size \\
\hline S & $\begin{array}{l}\text { Average annual saving } \\
1=\text { improved } 0=\text { not improved }\end{array}$ \\
\hline TOTLAD & Total land size of respondents owned (hec) \\
\hline
\end{tabular}

\section{RESULTS AND DISCUSSIONS}

Characteristics of Respondents

Of the total sample clients of the program, $85(58.22 \%)$ are male and $61(41.78 \%)$ are female. From the total sample non-clients, $73(56.15 \%)$ are male and $57(43.85 \%)$ are female. From the total sample respondents, $158(57.25 \%$ ) are male and $118(42.75 \%)$ are female (see table 4.5$)$. while the ages of respondents $110(39.85 \%)$ are in the range of $31-40,109(39.49 \%)$ are in the range of 41-50. This implies that the ages of most respondents lie in the range of age between 31 and 50 and the average age for frequent men clients was 42.3 years old and for women clients was 41 years. Whereas for men non clients, the age was 43.7 years and for that of women clients was 39.4years.

\section{Impacts of the Program at the Household Level Effect on Income Inequality at Household Level}

Microfinance directly eases the credit constraints on the poor and is expected to lower inequality. Microfinance also allows the poor to have access to financial services, make investments, and diversify their business, thus leading to an increase in their income. Moreover, microfinance offers not only financial services but also training with strong disciplines, which enables borrowers to increase their productivity. They can also cope with external shocks and achieve consumption smoothing. As such, microfinance enables the poor to increase their income, consumption, and productivity, which contributes to lowering inequality. A Gini coefficient is a numerical statistic used to measure income inequality within the society. It is a score between zero and one. A gini coefficient equal to one implies perfect income inequality while that of zero indicates perfect income equality. However, in reality there is neither perfect income equality nor perfect income inequality, that is why it lies between 0 and 1 . A high Gini shows income is concentrated among a few while a low Gini shows more equitable distribution of income (Atkinson and Bourguignon (2000). In his presentation at Columbia University on September 22, 2010, Ethiopia's late Prime Minister Meles Zenawi brought to the attention of the audience that the Gini coefficient of inequality of Ethiopia is about 0.29. In simple words, according to Prime Minister Meles Zenawi's statement, in recent years Ethiopia has not only registered rapid economic growth but the income from economic growth has been redistributed equitably. However, economic literature does not seem to support Ethiopia's Gini coefficient of 0.29 which is far below the Gini coefficient of newly industrialized countries (Desta, 2011). According to (Desta, 2011) the study that gave the entire world an impression that Ethiopia's Gini coefficient is 0.29 needs to be replicated by other sound methodologies in order to confirm or invalidate it. On the other hand, an effort was made to assess the distribution of income between sample clients and non-clients of ACSI in in Degadamot woreda and the result showed that the Gini coefficient for clients is 0.310 while for non-clients is 0.329 which means that the relative distribution of income for clients is more equitable than non-clients as it is indicated in table 4.14.the results of the Gini coefficient in this study implies two things. First, it is possible to say that participation in microfinance program tends to reduce income inequality relative to non-participants. This is also meant that the poor who get microfinance services are gradually relinquished themselves from poverty. Second, even if it is difficult to make inference, economic literature seems to support the Gini coefficient of this case study in contrast 
Table 3: Income inequality of sample respondents

\begin{tabular}{llcc}
\hline & \multicolumn{2}{l}{ Types of respondents } & Tot al \\
\cline { 2 - 3 } & \multicolumn{2}{l}{ Client } & \\
Number of observations & 146 & 130 & 276 \\
Sample Gini coefficient & 0.310207 & 0.329026 & 0.31933 \\
Estimate of population value & 0.312346 & 0.331577 & 0.320491 \\
\hline
\end{tabular}

Survey:2018

\section{Effect on Livestock Ownership of Respondents}

A generally accepted indicator and underlying determinant of poverty in Ethiopia is livestock ownership, although its role in the different livelihood systems may be different. Oxen are crucial in ox-plough farming systems in most of the Ethiopian Highlands. In the other farming systems, where oxen are less important for traction, livestock provide a very important source of additional income, via milk and meat, dung, etc. In all farming systems, livestock are the single most important store of wealth. Many studies found the correlation between poverty and livestock ownership (Dercon, 1999). In all the rural communities studied, (World Bank, 1998) found that owning no or very little livestock was a clear characteristic of the poorest part of the community.

The table 4 below indicates that the amount of livestock unit that the respondents have .If we compare the average tropical livestock unit of females between client and non-clients, in rural areas about 42 of female clients have a mean of 1.770 TLU while that female non clients have a higher average TLU which is 2.525 . while in urban areas female clients have $0.216 \mathrm{TLU}$ and that of non-clients 0.250 .similarly the relative possession of livestock between clients and non-clients for male respondents, table 34 also indicates that in rural areas about 59 male non clients do have higher TLU(2.720) while about 74 of sample clients have 2.648. It was also observed from the table that urban clients have higher TLU than non-clients. This may be due to client's program participation enables them to have a higher livestock unit than non-clients.

Table 4: Livestock units of sample respondents.

\begin{tabular}{|c|c|c|c|c|c|}
\hline Sex of respondents & $\begin{array}{l}\text { Location of } \\
\text { respondents }\end{array}$ & $\begin{array}{l}\text { Types } \\
\text { respondents }\end{array}$ & of & Frequency & Mean of TLU \\
\hline \multirow[t]{4}{*}{ Female } & Rural & Non client & & 32 & 2.525 \\
\hline & & Client & & 42 & 1.770 \\
\hline & Urban & Non client & & 25 & 0.250 \\
\hline & & Client & & 19 & 0.216 \\
\hline \multirow[t]{4}{*}{ Male } & Rural & Non client & & 59 & 2.720 \\
\hline & & Client & & 74 & 2.648 \\
\hline & Urban & Non client & & 14 & 0.196 \\
\hline & & Client & & 11 & 0.289 \\
\hline
\end{tabular}

Sample respondents were also asked whether their livestock unit were improved or not in the past two years.

Table 5: Trends in improvement of livestock units for respondents

Trends of livestock Types of respondents

Improved

\begin{tabular}{llll} 
Frequency & Percent & Frequency & Percent \\
\hline 94 & 64.38 & 72 & 55.39 \\
52 & 35.62 & 58 & 44.61 \\
\hline
\end{tabular}

Table 5 indicates that about $94(64.38 \%)$ of sample clients replied during the survey that the number of livestock increased in the past two years. It was only for $35.62 \%$ of clients that their livestock units were not improved. On the other hand, about 72(55.39\%) and 58(44.61\%) of non-client's livestock unit were not shown an improvement. if we compare simply the improvements in livestock between frequent clients and non-clients, the former showed a pronounced change. Two things can be noted here. First, microfinance participation would enable participants to create assets in the form of livestock provided that they used the loan for the predetermined intended purposes. Second, this study indicates that the role of microfinance intervention reduces the gap of asset ownership in terms of domestic animals between the rich and the poor.

\section{Estimates of the Logit Model}

Assessing impact at the participant level requires adjustments to control for differences between frequent borrowers who are taken as clients and those who are looking for credit that are taken as non -clients. The impact of the program is assessed based on the variables indicated above. The variables used in regression are respondents 
who are clients and non-clients, loan size, sex of respondents, age of respondents, settlement of respondents, level of household education, size of the household, average annual amount of loan, tropical livestock unit and total land.

The dependent variable is variable which takes a value of 1 or 0 depending on whether the respondents' income improved or not. The Logit model specifies the functional relationship between the probabilities of respondents being improved in program participants and indicated various quantitative and qualitative explanatory variables of each group. Thus, the impact is analyzed based on the following results of the model through the coefficients of each variable.

Table 6:

Table 2: Estimates of the Logit Model of the Total Respondents

\begin{tabular}{|l|l|l|l|l|}
\hline Income & Coefficient & Standard error & p- Value & 95\%CI \\
\hline RESPO & 1.073 & 0.408 & 0.009 & 0.273 \\
\hline LS & 0.00098 & 0.00021 & 0.0045 & -0.0005 \\
\hline SEX & 0.734 & 0.383 & 0.054 & -0.013 \\
\hline AGE & 0.060 & 0.027 & 0.641 & -0.059 \\
\hline SETR & 1.088 & 0.995 & 0.172 & -0.471 \\
\hline HHEDU & 0.138 & 0.073 & 0.057 & -0.004 \\
\hline HHSIZ & 0.103 & 0.148 & 0.487 & -0.0037 \\
\hline S & 0.0035 & 0.001 & 0.002 & 0.0012 \\
\hline TOTLAD & 1.487 & 0.68 & 0.029 & 0.153 \\
\hline
\end{tabular}

The direction of change in the probability of improvement in income in relation to the explanatory variables is explained based on the sign of the coefficients. The parameters tell how the economic status of the clients and non-clients changes with the change in explanatory variables. On the other hand, the positive sign of the parameters shows the trend that the changes of the variable are greater in clients than non-clients. Therefore, Table 6 indicates that the average annual income $(\mathrm{Y})$ is positively related to program participation indicating that the probability of improvement in income increases with the increase in program participation. The coefficient is statistically significant at $5 \%$ significance level. It implies that clients showed higher improvement in income than non-clients. In addition, there was a positive relationship between average annual income and gender of respondents particularly the probability of improvement in income was significantly higher for male respondents than for females. It was also observed from the study that there was a positive relationship between loan size and probability of an improvement in income which is statistically significant at $5 \%$ level of significance.

Besides, the probability of increase in income had positive relation with settlement of the respondents. This may indicate that urban areas were better than rural areas. However, the difference was statistically insignificant. There was also a positive relationship between improvement in income and household education. It indicates that the probability of improvement in income for sample clients was significantly higher than for non-clients at $5 \%$ level of significance. From the analysis, it was observed that household size was helpful for the increase in the trend of income. This is to mean that when household size increases, income tends to increase given that the maximum household size in this study was eight. This was also evidenced in much of the developing world that child labor is utilized as source of income in the households' economic engagement area. In addition to this some of the household members whose ages are below 18 would send across households in the form of house servant particularly females, looking after cattle, for ploughing land and in the form of daily laborer.

The finding indicates that as age of the respondents increase, trend of income was found to exhibit a positive sign. This is perhaps because experience would help people to accumulate knowledge and new ways of doing things. Consequently, they would be able to care about their income when they grow aged. However, the differences between the respondents were statistically insignificant. Land size was also found to have positive relation with trend of income. The reason is straightforward. The larger the size of land, the more will be the chance to produce more provided that agricultural inputs and other methods of proper farming are put in place. This was also statistically significant according to the logistic regression results indicated in table 2 . It was also considered that the direction of change in income also shows a positive relationship with the amount of individual voluntary savings. The regression coefficient shows the expected sign, which is also statistically significant at $5 \%$ significant level. This implies that the probability of the improvement in income increases with the increase in individual voluntary saving. Here it was possible to say that the program introduces the saving habits to the poor.

\section{Findings and Conclusions}

Assessing the impact of microfinance intervention is essential to explore the ways in which financial services are able to support livelihoods and promote them for savings accumulation for future use. Descriptive analysis and binary logit model were used to analyze the impacts of ACSI on poverty reduction. Since the objective of the study is to find out whether the delivery of financial services by ACSI has made changes on economic statuses of the 
poor, the study found the following results and conclusions.

In the study area, most of the sample respondents from the frequent clients $118(80.82 \%)$ were found to register an increasing trend in their income for the last two years in comparison with non-clients (control 73 (56\%).

The study also showed that participation in microfinance program reduces the income inequality between clients and non-clients. The Gini coefficient for clients is 0.310 while for non-clients it is 0.329 which means that the relative distribution of income for clients is more equitable than non-clients.

The study showed that about $94(64.38 \%)$ of sample clients replied during the survey that the number of livestock they have increased in the past two years. On the other hand, about $72(55.39 \%)$ and $58(44.61 \%)$ of nonclient's livestock unit were not shown an improvement. The findings of study indicated that the improvements in livestock units were higher for clients than non-clients. Two things can be noted here. First, microfinance participation would enable participants to create assets in the form of livestock provided that they used the loan for the predetermined intended purposes. Second, this study indicates that the role of microfinance intervention reduces the gap of asset ownership in terms of domestic animals between the rich and the poor.

The immediate positive impact of micro financing scheme is on employment generation. The average annual income $(\mathrm{Y})$ is positively related to program participation indicating that the probability of improvement in income increases with the increase in program participation. The coefficient is statistically significant at $5 \%$ significance level. It implies that clients showed higher improvement in income than non-clients. In addition, there was a positive relationship between average annual income and gender of respondents particularly the probability of improvement in income was significantly higher for male respondents than for females. It was also observed from the study that there was a positive relationship between loan size and probability of an improvement in income which is statistically significant at $5 \%$ level of significance.

It was observed that household size was helpful for the increase in the trend of income. This is to mean that when household size increases, income tends to increase given that the maximum household size in this study was eight. This was also evidenced in much of the developing world that child labor is utilized as source of income in the households' economic engagement area. In addition to this some of the household members whose ages are below 18 would send across households in the form of house servant particularly females, looking after cattle, for ploughing land and in the form of daily laborer.

As a policy indicator, the intervention of micro finance is expected to improve the living standard of the poor. As such it improves the economic status of the society and country as a whole. The result indicates the trend that the program improves their live conditions implying microfinance is becoming a tool for poverty reduction. It also implies that program participants have been benefited in improving their basic needs. As stated in the study, the services of the program are found to be encouraging with the needs of the poor.

It is expected to have positive contribution to clients in relation to income, access to education and medical care, employment generation, savings and resource empowerment. Therefore, strengthening the existing institution in the region would be appropriate economic policy.

\section{References}

AEMFI (2003) Microfinance Development Review: Rural Financial Intermediation Program and its role in strengthening the Rural Finance System in Ethiopia. Vol.3, No. 2: Addis Ababa, Ethiopia

Amhara Livelihood Profile, "Population by Livelihood Zone and Kebele" 2005

Assefa A.,Gebrehiwot A. and Mulat D.(2005) Rural Finance in Ethiopia: Assessment of the Financial Products of Microfinance Intuitions. AEMFI, Occasional paper No.12: Addis Ababa, Ethiopia.

Attimir O. (1982) The Extent of Poverty in Latin America: World Bank Staff Working Papers. No .522. The World Bank: Washington D.

AIMS (2000) Learning from clients Assessment Tool for Microfinance practitioners. Washington D.C.,USA.

RAlderich and Nelson (1984) Linear Probability, Logit and Probit Models.Sage Pub. Inc.,University of Minnesota and Iowa. Newdehli, London

Asmelash B. (2003) The Impact of Microfinance in Ethiopia: the case of DCSI in Ganta Afeshum district of Eastern Tigray. M.A.Thesis, Department of RLDS, AAU.

Bamlaku Alami rew (2004), Microf inance and Development in Living Standards of poor pathway out of pover ty: the case of Enemy woreda, Eastern Gojam. MA Thesis, Addis Ababa Universi ty.

Berhanu L. (1999) Micro enterprise credit and Poverty Alleviation in Ethiopia: The case of the project Office for the creation of Small-Scale Business Opportunities in Addis Ababa, MA Thesis, department of Economics, Addis Ababa University.

Bigsten A et al (1999) Poverty and Welfare in Ethiopia: Profile and Determinants. In: Tassew Woldehanna et al (eds) Poverty and Poverty Determinants in Ethiopia, Ethiopian Journal of Economics, Vol VIII, No 1, Addis Ababa, Ethiopia.

Bigsten et al (2002) Growth and Poverty Reduction in Ethiopia: Evidence from Household Panel Surveys, Working Paper in Economics No. 65, Department of Economics, Gotenburg University. 
Buckley,G.(1997) "Micro finance in Africa: Is it either the problem or the solution?", World Development 8(7)1081-1094.

Chekol Kidane (2002) "Microfinance in Tigray, Ethiopia: Its impact on poverty alleviation."(Unpubilished).

Cohen, Monique (2000) “Evolution of Microfinance.” Video conference, Washington, D.C.,USA

CIA (2005) The World Fact Book: Ethiopian Population, Ethiopia.

CSA, "The 2007 Population and Housing Census of Ethiopia: Statistical Report for Amhara Region; Part I: Population Size and Characteristics"

Daba Moti (2004) The Impact of Micro-financing on Poverty Reduction: A case Study of Oromia Credit and Savings S.Co. A Paper Presented in the International Conference on Micro-finance Development in Ethiopia, January 21-23, 2004, Awassa, Ethiopia.

Ellis, Frank (1992) Agricultural Policies in Developing Countries. Cambridge University Press, Cambridge

Fiona M. (2000) Impact of Micro Credit at Household. In; Mulat Demeke's (ed.) in The development of Micro finance in Ethiopia, Proceeding of the Conference on Micro finance Development in Ethiopia, Bahr Dar, Ethiopia.

Foster, J et al (1984) A Class of Decomposable Poverty Measures, Econometrica 52:761-766.

Gaile, Gl \& Foster, J (1996) Review of Methodological Approaches to the Study of the Impact of Goetz, A.M., and R. Sen Gupta. (1996). who takes credit? Gender, power, and control over loan use in rural credit program in Bangladesh. World development 24(1): 45

Getahun T. (1999) Poverty and Poverty Reduction in Ethiopia: In Aspects of Development Issues in Ethiopia Proceedings of Workshop on the Twenty-Fifth Anniversary of the Institute of Development Research in Tegegne G. et al. Gujarati D. (1992) Essentials of Econometrics. Singapore

Gillespie N.(1990), "Selected World Bank Poverty Studies: A Summary of Approaches, Coverage, and Findings" world bank,

Haughton J.and Khandker S.(2009) "Handbook on Poverty and Inequality", The World Bank Washington, D.C.

Hossain, M. (1988) "Credit for Alleviation of Rural Poverty: The Grameen Bank in Bangladesh", IFFPRI Paper No.65 Washing to D.C.

Hulme D (1997) "Impact Assessment Methodologies For Microfinance: A Review Paper prepared in conjunction with the AIMS Project for the Virtual Meeting of the CGAP Working Group on Impact Assessment Methodologies" (April 17-19, 199)

Hulme D (2000) "Impact Assessment Methodologies for Micro Finance: Theory, Experience and Better practice". World Development. Vol.28, No.1, pp79-98.

Hulme D and Mosley P. (1996). Finance Against Poverty: Effective Institutions For Lending To Small Farmers And Microenterprises In Developing Countries. Routledge, London.

Johnson S. and Rogally( 1997) Micro finance and poverty Reduction, Oxfam (UK and Irela

Khan A. and Rahaman A. "Impact of Microfinance on Living Standards, Empowerment and Poverty Alleviation of Poor People": A Case Study on Microfinance in the Chittagong District of ,Bangladesh, Master's thesis.

Khandker S. (2003) Micro - Finance and Poverty: Evidence Using Panel Data from Bangladesh; World Bank Policy Research Working Paper 2945.

Ledgerwood, J. (1999) Sustainable Banking with the Poor: Micro finance hand Book, An Institutional and Financial Perspective, Washington, D.C.

Maddala G.S.(1983) Limited Dependent and Qualitative Variables in Econometrics. New York: Cambridge University Press

Meehan,Fiona (2001), Usage and Impact of Microcredit Provision: A case study based on the credit operations of Dedebit Credit and Saving Institution (DECSI), Tigray, Ethiopia. A paper submitted to an international Workshop on Dimensions of Microfinance Institutions in Sub Saharan Africa - Relevance of international Experince Mekelle University, Mekelle.

Morduch, Jonathan (December 1999), Journal of Economic Literature, Vol.XXXXII (pp 1569 - 1611).

MoFED (2002) Ethiopia: Sustainable Development and Poverty Reduction Program, Addis Ababa, Ethiopia

Morgan, S. Philip and Teachman, Jard.(1988)."Logistic Regression: Description, Examples, and Comparisons." Journal of marriage and the family: 929-936.

Rahman Rc (1996) "Impact of Gramen Krishi Foundation on the Socio economic condition of Rural HHs" BIDS Working Paper No.7 BIDS, Bangladesh Institute of Development Studies, Dhaka

Rogally,B. (1996) "Micro finance Evangelism, Destitute Women, and the hard selling of a new anti-poverty formula", Development in Practice6(2), 100-112

Ramanaiah .V and Gowri .M (2011) "A review of Ethiopian institutions and their role in poverty reduction": A case study of Amhara Credit and Saving Institution (ACSI)

Stewart R, van Rooyen C, Dickson K, Majoro M, de Wet T (2010), "What is the impact of microfinance on poor people? A systematic review of evidence from sub-Saharan Africa.

Technical report”. London: EPPI-Centre, Social Science Research Unit, University of London. 
Tsehay T and Mengistu B. (2002). The Impact of Microfinance Services among Poor Women in Ethiopia. Occasional Paper No. 6, AEMFI, Addis Ababa

UNDP (1998) Human Development Report, London, Oxford University Press. University Press.

Teferi Z. (2000) Micro finance and the Poor: The case of Dedebit Credit and saving Institution in Tigray, MA Thesis, department of Economics, addis Ababa university

The Ethiopia Macroeconomic Handbook (2 01 0),www.accesscapitalsc.com

Todaro M.P. (1997) Economic Development, 6th (edn.). Third Impression: New York.

Wolday Amha. (2000) Review of micro finance industry in Ethiopia: regulatory frameworks and performance, Occasional Paper No. 2 , Addis Ababa, Ethiopia

Wolday A. (2001). Development of Microfinance Industry in Ethiopia: Performance, Problems and Prospects. A Paper Presented For The 11th Annual Conference of the Ethiopian Economy. Adama (Mimeographed)

Wolday A. (2002). Product Development in Ethiopia MicroFinance Industry: Challenges and Prospects. (Ed.)Zaid N. et al. Micro Finance Theory Policy and Experience Proceedings of the International Workshop on "The Dimension of Micro Finance Institutions in Sub Saharan Africa: Relevance of International Experience." Mekelle University

Wolday A. (2003) Microfinance in Ethiopia: Performance Challenges and Role in Poverty

Reduction. Association of Microfinance Institutions. Occasional paper No. 7, AEMFI: Addis Ababa, Ethiopia.

Wood G.and Sharif, S. (1997) Where Credit is due, Dhaka and London: UPLand Zed Press.

World Bank (1990) Selected World Bank Poverty Study, Working Paper, WPS 552, Washington, DC.

World Bank (1991) Vocational and Technical Education and Training. Policy Paper,

Washington, D.C.

World Bank (1992) Ethiopia towards Poverty Alleviation and a Social Program, Washington,DC. World Bank (1999) African Development Indicators, Washington, DC.

World Bank (2002) Empowerment and Poverty Reduction: A Sourcebook World Bank (1999). World Development Report 2000/2001. Oxford University Press, Washington D.C

World Bank (2001) World Development Report 2000/01: Attacking Poverty, Oxford University Press. World Bank (2002) World Development Report 2002/03, Washington, D.C.

World Bank (2003). World Development Report 2002/2003. Oxford University Press, Washington D.C. World Development Report (2000/2001). "Attacking Poverty". Published for the World Bank Oxford University Press

Yaron J. Bejamin etal (1997), Rural Finance issues design and best pract ices Washington D.C. agr icul ture and natural resources depar tment, Wor ld Bank 